\title{
AEROMAGNETIC MAP OF THE GAP QUADRANGLE, LANCASTER COUNTY, PENNSYLVANIA \\ By
}

Randolph W. Bromery, Gerald L. Zandle, and others

\section{GEOPHYSICAL INVESTIGATIONS \\ MAP GP-245}

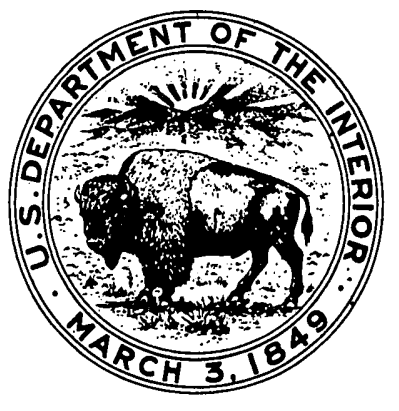

PUBLISHED BY THE U. S. GEOLOGICAL SURVEY 